\title{
Lung Change Pattern On Domestic Cat (Felis Silvestris Catus) Exposed By Factory Air Pollution With X-Ray Thorax Interpretation
}

\author{
Ratna Widyawati ${ }^{1}$, Desty Apritya², Junianto Wika Adi Pratama ${ }^{4}$, \\ Asnizar Fahmi ${ }^{3}$
}

\author{
${ }^{1,2,3}$ Department of Clinical Veterinary, ${ }^{4}$ Departement of Basic Medicine Faculty of \\ Veterinary Medicine, Wijaya Kusuma Surabaya University, Surabaya 60225, Indonesia \\ *Corresponding author: Ratna Widyawati (ratnawidyawati@uwks.ac.id)
}

\begin{abstract}
The pathology density changes for X-Ray interpretation of the lungs are difficult to distinguish, because the disease is not easily classified and may represent a variety of lung disorders. The study was aimed of this research to found the lung disease of domestic cats (Felis Silvestris Catus) that exposure to air pollutions in the industrial area of region Manyar, district Gresik. The type of this research was observational study Explorative that using the simple random sampling and observed nine cats for the sampling. The results of X-ray Thorax in this research showed that there are changing in the $3 \mathrm{rd}, 4$ th, 5 th, 6th, 7th, an 9th of the sampling cats. On the third, fifth and the seventh of the cats, we found the same condition that there was change the vascular patterns that were enlargement, vascular constriction or ambiguity structures. From the results of the vascular patern indicate the disorder of left-sided heart failure (Mitral Isufisiency) or obstruction of the left atrium. On the fourth of the cat, there was bronchial pattern that showed the classification, dilatation and thickness of the lung. On the sixth of the cats, there were changes on interstitial pattern with the pictures of nodulars that were not structures and on the ninth of the cats, we can found the same conditions with the fourth and the sixth of cats were visible Interstitial Pattern and Bronchial Interstitial Pattern.
\end{abstract}

Keywords: Lung pattern, Air pollution, X-Ray Interpretation, Thorax, Domestic cats.

Copyright $\odot 2020$ JRVI. All rights reserved.

\section{Introduction}

The lungs is one of the vital organ in the body. The lung is respiratory organs associated with the circulatory system. Lung function is as a place for exchanging oxygen with carbon dioxide in the blood. One thing to watch out for lung disorders is Chronic Obstructive Pulmonary Disease (COPD) or called Chronic Obstructive Pulmonary Disease (COPD), because it is not widely known to the wider community (Suradi, 2007).

Diseases that attack the lungs not only in humans, but also in cats. According to Yudi (2009) that lung disease in cats is very complex, it means that in one animal suffering it might be found many clinical symtoms, they are conjunctivitis, lacrimation, salivation and oral ulcerations. The lung disease that often occurs in cats is obstructive lung disease and allergies, often referred to asthma, bronchitis, or bronchial cancer. However, this disease is not easily classified and may 
represent a variety of lung disorders. The disease is referred to as "hyper-responsive" (overreactive) airways.

Lung disease in cat can range from mild or normal and can be a health disorder that has the potential to be bad diagnose (infausta) to the cat, whether chronic or acute depending on the level of severity of exposure to air pollution or the duration of exposure to the air pollution. It cause an impact on our health, if we get the cumulatively exposed. This health impact does not depend on whether the cumulative exposure comes from exposure to a brief but high (acute) level or on exposure at a low level but all the time (chronic). The result is the occurrence of pain (morbidity) and death (mortality). (Ali, 2007).

Air pollution can cause health problems in different levels and types, depending on the type, size and chemical composition. The disorder mainly occurs in physiological functions of body organs such as lungs and blood vessels, irritation to the eyes and skin. Air pollution due to dust particles usually causes respiratory diseases such as bronchitis, asthma, lung cancer. Pollutant gases dissolved in the air can directly enter the lungs and are then absorbed by the circulatory system (Kemenlh, 2007).

Air pollution is a condition of change (reduction or addition of air composition) compared to normal conditions in a certain time, place and concentration such that it endangers the life and health of the community. According to PP No. 41 of 1999, air pollution is the entry or insertion of substances, energy, and other components into the air by human activities, so that the air quality drops to a certain level that causes air to not be able to fulfill its function (Ali, 2007).

According to Wardhana in Sugiarti (2009) the world is known for the main air pollutants that come from human activities in the form of exhaust gases from burning fossil fuels and industry. The estimated percentages of major air pollutants in Indonesia, especially transportation and industry, are Carbon monoxide (CO) $70.50 \%$, Sulfur Oxide (SOx) $0.9 \%$, Nitrogen Oxide (NOx) 8.9\%, Particulates (PM) $1.33 \%$, Hydrocarbons (HC) 18.34\%, Greenhouse Gases (CH4, $\mathrm{CO} 2$ and $\mathrm{N} 2 \mathrm{O}$ ), distributed as a percentage of the main source.

Data from the Central Statistics Agency (BPS) in 2004 also explained that in several provinces, especially in big cities such as Medan, Surabaya and Jakarta, motor vehicle emissions constituted the largest contribution to the concentration of $\mathrm{NO} 2$ and $\mathrm{CO}$ in the air which amounted to more than $50 \%$. The continuous decline in air quality over the past few years shows us how important it is to promote efforts to reduce emissions by counseling industry and society or by conducting research for the application of emission reduction technologies (Simanjuntak, 2007).

According to Simanjuntak (2007), the types of pollution that are often formed by the results of human behavior are, Carbon Monoxide (CO) is a vehicle exhaust gas is the main source for carbon monoxide in various cities. Data reveals that $60 \%-70 \%$ of air pollution in Indonesia is caused by moving objects or public transportation that is fueled such as, Nitrogen Oxide (NOx) Until 2000 NOx originating from marine transportation, Gas Nox is formed of three functions namely; Temperature (T), Reaction Time ( $t$ ), and Oxygen concentrations (O2), NOx $=f(T, t$, O2), Sulfur Oxide (SOx) where SOx emissions are formed from the function of sulfur content in fuels, in addition to sulfur content in lubricants, also causes the formation of Sox emissions, Hydrocarbons $(\mathrm{HC})$ where Hydrocarbon Emissions $(\mathrm{HC})$ are formed from various machines which are sources of pollutants, Particulate Matter (PM) is dust particles in exhaust gas emissions consisting of various components, not only in the form of solids but also in the form of liquid that settles in dust particles, greenhouse gases $(\mathrm{CH} 4, \mathrm{CO} 2, \mathrm{~N} 2 \mathrm{O})$. Greenhouse gas is an 
appropriate term used for gases that cause an increase in global temperature. These gases in the air form a shield that blocks the geothermal heat caused by human activities and nature itself.

The principle of air pollution is when there are pollutants in the air (commonly called pollutants both primary and secondary originating from natural activities and most of human activity) that can affect normal air balance and cause disruption to human, animal and plant life and other objects. Sulfate dioxide (SO2), Carbon monoxide (CO), Particulate Matter, Hydrocarbons (HC), Nitrogen Oxide (NO2) Photochemical Oxidant, Tin (Pb), Ozone and Volatile Organic Compounds (VOC), are pollutants sourced from anthropogenic which can pollute the air, as well as cause health problems, also cause damage to the environment (Ali, 2007).

According to Simanjuntak, (2007) which is presented in a table below the effects or effects of air pollution on living things. The range of values shows the boundaries of regional categories according to the level of health for humans. Carbon monoxide, nitrogen, ozone, sulfur dioxide and particulate matter are some of the dominant air pollution parameters produced by pollutant sources. Based on the observation, it is known that some cities in Indonesia are included in the unhealthy category. This category refers to ISPU (Air Pollution Standards Index).

According to Suyatno (2008). X-ray radiation is an electromagnetic wave with short waves. Electromagnetic waves are many types including light rays, ultra violet, infrared, radio waves, and TV. X-rays have a high degree of penetrability to the material in their path. Thus X-rays can be used as a diagnostic and therapeutic tool in the field of medicine. $X$-rays can penetrate materials, such as body tissue, water, wood or iron, because $X$-rays have very short wavelengths. $X$-rays can only be effectively resisted by materials that have high density, such as lead $(\mathrm{Pb})$ or thick concrete, $\mathrm{X}$-rays or $\mathrm{X}$-rays are a form of electromagnetic radiation with wavelengths ranging from 10 nanometers to 100 picometers (similar with a frequency in the term $30 \mathrm{PHz}$ to $60 \mathrm{EHz}$ ). X-rays are commonly used in the diagnosis of medical images and $\mathrm{X}$ ray crystallography. $X$-rays are a form of ionizing radiation and can be dangerous.

The study aimed to detect normality or health and abnormalities of the cat's lungs due to stay and grow big by breathing factory air pollution because $\mathrm{X}$-ray function through body tissues, especially the lungs such as cat lungs.

\section{Materials and Methods}

\section{Orientation in cats dan tools}

Domestic cats (Felis silvestris catus or Felis catus) with a body weight of approximately $2-3 \mathrm{~kg}$ and located or living in or in the factory area. The tools was used were as follows cages to catch cat samples that are distinguished from cages for raising cats for immediate scanning with X-ray equipment.

\section{Interpretation of radiographic images}

From the results obtained, it can be seen how the respiration system works to the lung state of each cat sample and find out the abnormality or disturbance in the lung of the sample cat by interpretation the results of X-Ray photographs. The result can be radiopaque.

\section{Processing the procedure for taking the cat for radiographic images}


Research Procedure: Cats that have been obtained and collected must comply with the weight criteria of approximately $2-3 \mathrm{~kg}$ weighed and grouped in each cage. The cats that have been obtained are then cleaned (if dirty) and prepared for immediate examination standards (palpation, percussion, auscultation) as well as ambulatory filling and prepared for X-Ray. Thorax on each cat to be found until all $X$-ray imaging results are found thorax all cats.

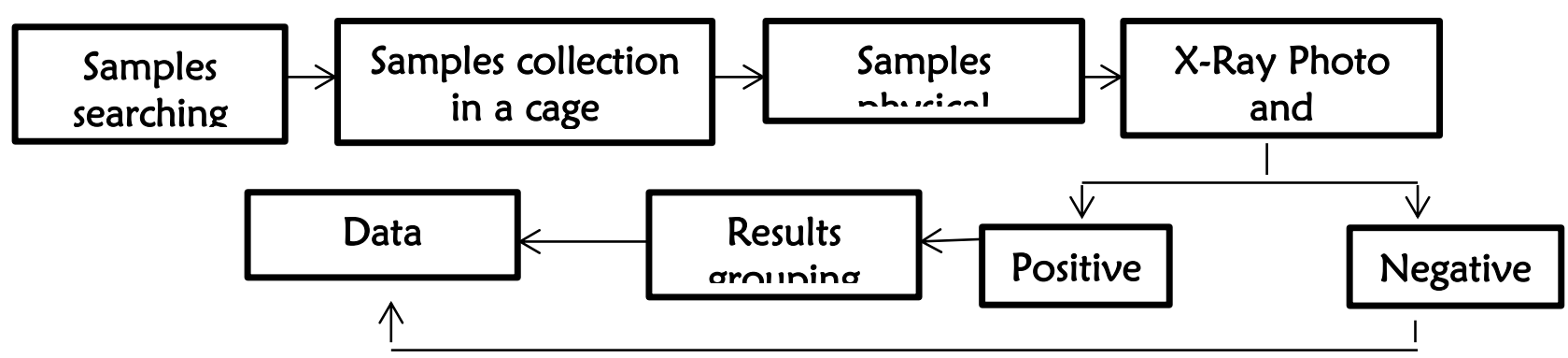

Figure 1. Stages of processing to analyse the thorax $x$-ray interpretation of radiographic images

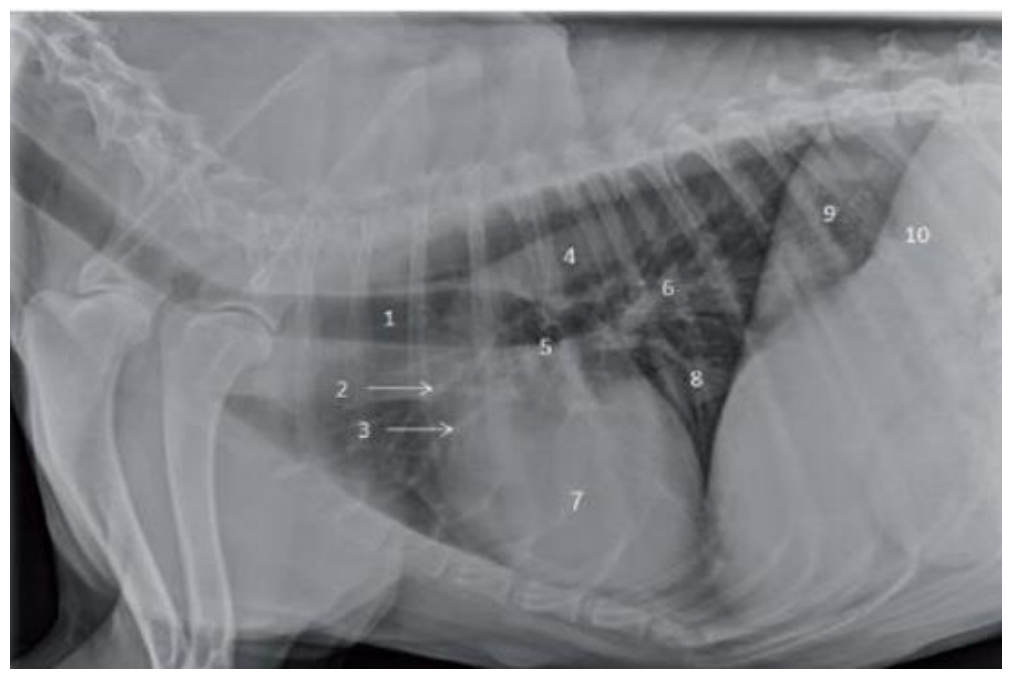

1. Trachea

2. Cranial lobe pulmonary artery

3. Cranial lobe pulmonary vein

4. Descending aorta

5. Carina
6. Caudal lobar pulmonary arteries and veins (superimposed)

7. Heart

8. Caudal vena cava

9. Left crus of the diaphragm

10. Right crus of the diaphragm

(Widyananta, B J dkk, 2017)

Figure 2. Normal X-Ray Interpretation of Thorax cavity 


\begin{tabular}{|c|c|c|}
\hline Pattern of lung disease & change & Figure \\
\hline Vascular pattern & $\begin{array}{l}\text { 1. Seen as soft tissue } \\
\text { radiopacity } \\
\text { 2. Larger in the hillar and } \\
\text { central portions } \\
\text { 3. The right cranial lobar } \\
\text { artery and vein should be } \\
\text { paired and the same size } \\
\text { 4. Diameter of each should } \\
\text { not exceed the smalest } \\
\text { diameter of the right } 4 \text { th } \\
\text { rib (lateral view) } \\
5 . \text { Vein diameters caudal to } \\
\text { the } \\
9 \text { th exceed the diameter of } \\
\text { the 9th rib caudal lobar } \\
\text { veins enlarged VD/DV } \\
\text { view). }\end{array}$ & 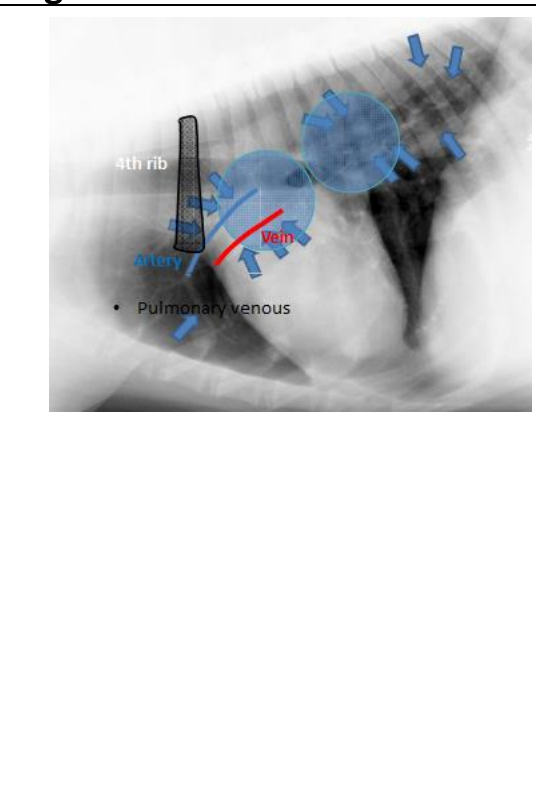 \\
\hline Interstitial pattern & $\begin{array}{l}\text { 1.The interstitium of the } \\
\text { lung surrounds and } \\
\text { supports the alveoli, } \\
\text { pulmonary vessels, and } \\
\text { bronchi } \\
\text { 2.Interstitial space is not } \\
\text { filling with fluid, exudate, } \\
\text { interstitial edema }\end{array}$ & Case with interstitial pattern \\
\hline Peri/Bronchial Pattern & $\begin{array}{l}\text { 1. Bronchiole wall is } \\
\text { covered in fluid, more } \\
\text { radiopaque and } \\
\text { therefore contrasts very } \\
\text { well against the } \\
\text { radiolucent lumen } \\
\text { 2. Cross section the } \\
\text { bronchiole appears as a } \\
\text { radiopaque circle with a } \\
\text { radiolucent center donut } \\
\text { like } \\
\text { 3. Longitudinally it appears } \\
\text { as two parallel } \\
\text { radiopaque lines railroad } \\
\text { track }\end{array}$ & $\begin{array}{l}\text { Case with Peri/Bronchial } \\
\text { pattern }\end{array}$ \\
\hline Alveolar Pattern & $\begin{array}{l}\text { A silhouette sign which is } \\
\text { the inability to see } \\
\text { margins of the heart, } \\
\text { vessels, and diaphragm. }\end{array}$ & Case with Alveolar pattern \\
\hline
\end{tabular}




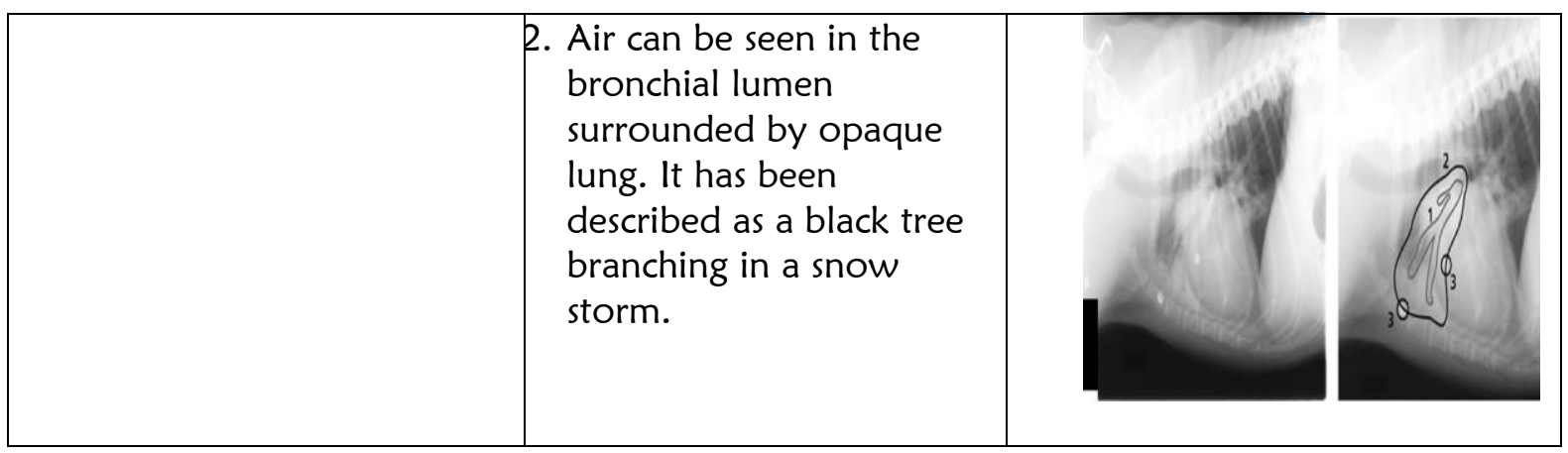

(Widyananta, B J dkk, 2017)

\section{Measurement of lung pattern changes :}

The implementation for interpretation of pulmonary disesase on the chest radiograph of thorax is necessary to consider a number of things, the first radiographic signs caused by pulmonary disease. In this case, it must be distinguished from radiographic images arising from extrapulmonary diseases, such as extrathorax, pleural and mediastinal diseases. The second is radioopacity. Third is loss of detail in general and decrease of size of blood vessel. The fourth appears and sharpens details that should not be visible, for example enlargement of blood vessels or boundaries that appear dilated. The five normal structural displacements from the cardiovascular, thrachea, bronchi, pulmonary vascularity and diaphragm. Sixth emergence of different patterns of changes from lung patterns. The patterns if increased pulmonary opacity are: Vascular pattern thar occure enlargement, contriction or vagueness of the vascular structure. Bronchial pattern, which is calcification, dilatation or thickening. Interstitial pattern is nodular structured and unstructured nodular. Alveolar pattern, which increases pulmonary parenchymal radioopacity. In practice a mixed pattern can occure (Sektiari B, 2007).

\section{Data Analysis}

Data analysis was generally done by connecting what has been obtained from an initial work process. This is intended to understand the data collected from the source, which is then known to the researchers' framework. The data analysis method used in this study was Content analysis or what was called content analysis was a method for understanding discourse or problems by finding the core of the discourse. So researchers in this method will analyze the data based on the results obtained in the field and the results obtained from the results of the treatment in the Domestic Cat sample (Felis silvestris catus or Felis catus) using X-Ray interpretation.

\section{Results and Discussions}

\section{Pattern of Lung Disease}

There are four pattern of lung disease, they are Vascular pattern, Interstitial pattern, Bronchial pattern and Alveolar pattern. Vascular pattern is pulmonary venous distention or enlargement failure of left side heart resulting less blood is ejected, then preload (fluid volume) to the left side of the heart becomes elevated. 


\section{Lung X-Ray Interpretation}

The results of the research that has taken place in the Manyar Industrial Area, Gresik Regency, were then taken X-ray photographs at the Healthy Animal Clinic, Sidoarjo as follows:

Table 2. Results of Lung X-Ray Readings

\begin{tabular}{|c|c|c|c|}
\hline Sample & $\begin{array}{c}\text { Age } \\
\text { (years) }\end{array}$ & Lungs & Lung pattern \\
\hline Cat 1 & 2 & No changed & Normal \\
\hline Cat 2 & 1 & No changed & Normal \\
\hline Cat 3 & 1 & Changed & Vasculer and Vena Pulmoner \\
\hline Cat 4 & 1 & No changed & Interstitial (unstructure) \\
\hline Cat 5 & 1 & Changed & Vasculer and Vena Pulmoner \\
\hline Cat 6 & 1 & Changed & Peribroncial \\
\hline Cat 7 & 1.5 & Changed & Vasculer \\
\hline Cat 8 & 1 & No changed & Normal \\
\hline Cat 9 & 2 & Changed & Interstitial and Peribroncial \\
\hline
\end{tabular}

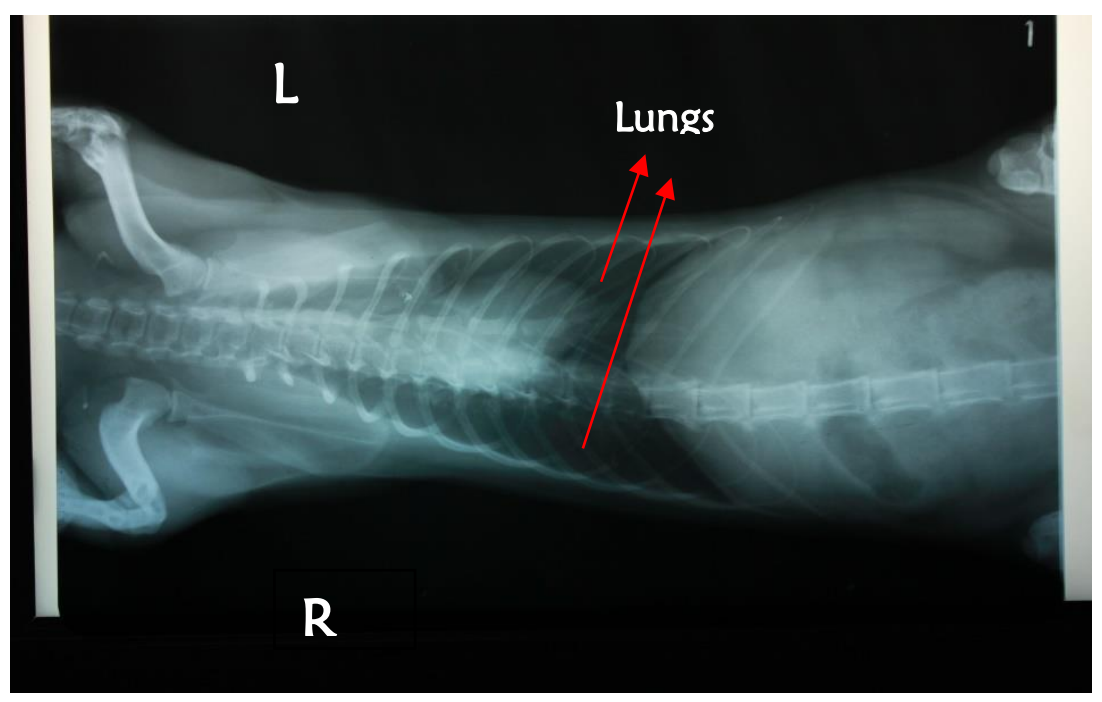

Figure 3. X-Ray Thorax Cat 1.

Sample 1. In the Ventro-Dorsal position we found the result of a normal lungs. Indications of a normal X-ray image of the thorax were radiolucent (black) in the lungs without a radiopaque (white) pattern forming in the lung. 

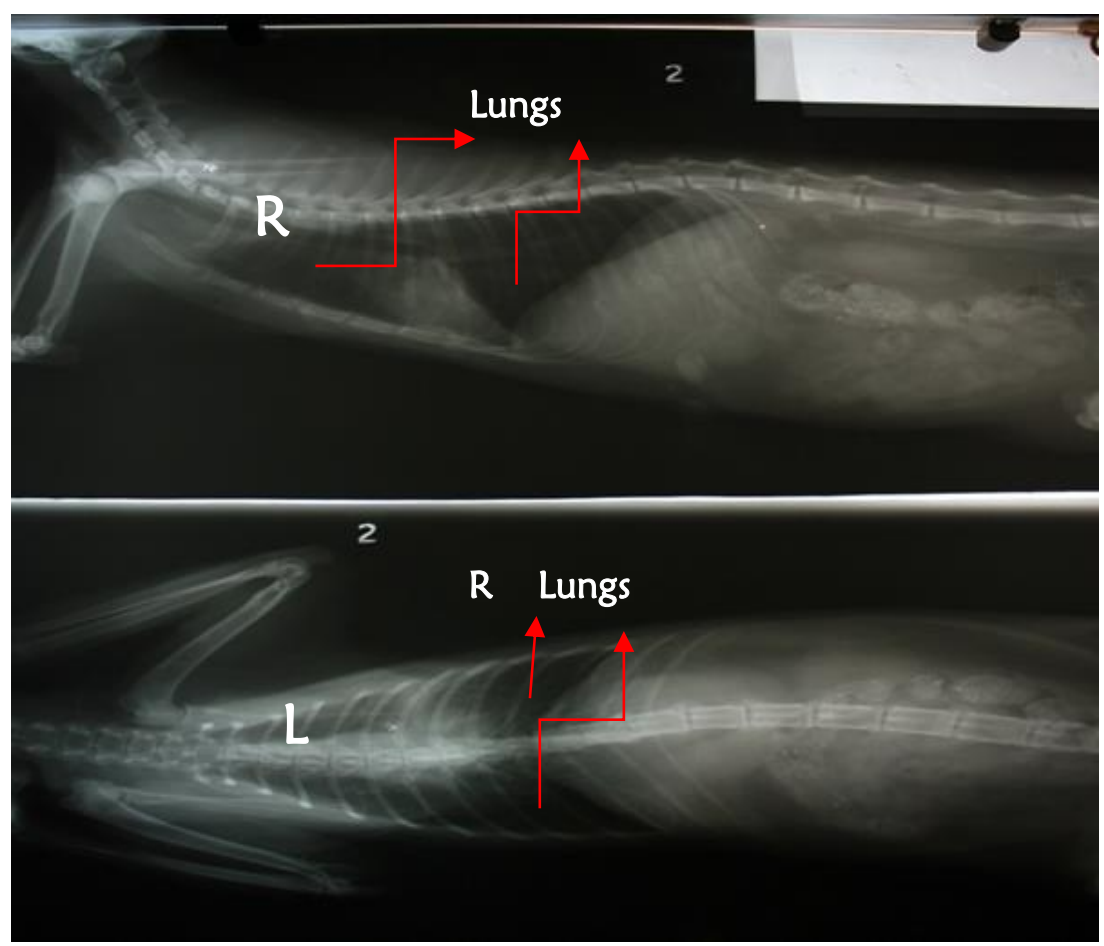

Figure 4. X-Ray Thorax Cat sample 2, In the Lateral position (top X-ray figure) and Ventrodorsal (lower $\mathrm{X}$-ray photo)we found the normal lungs.

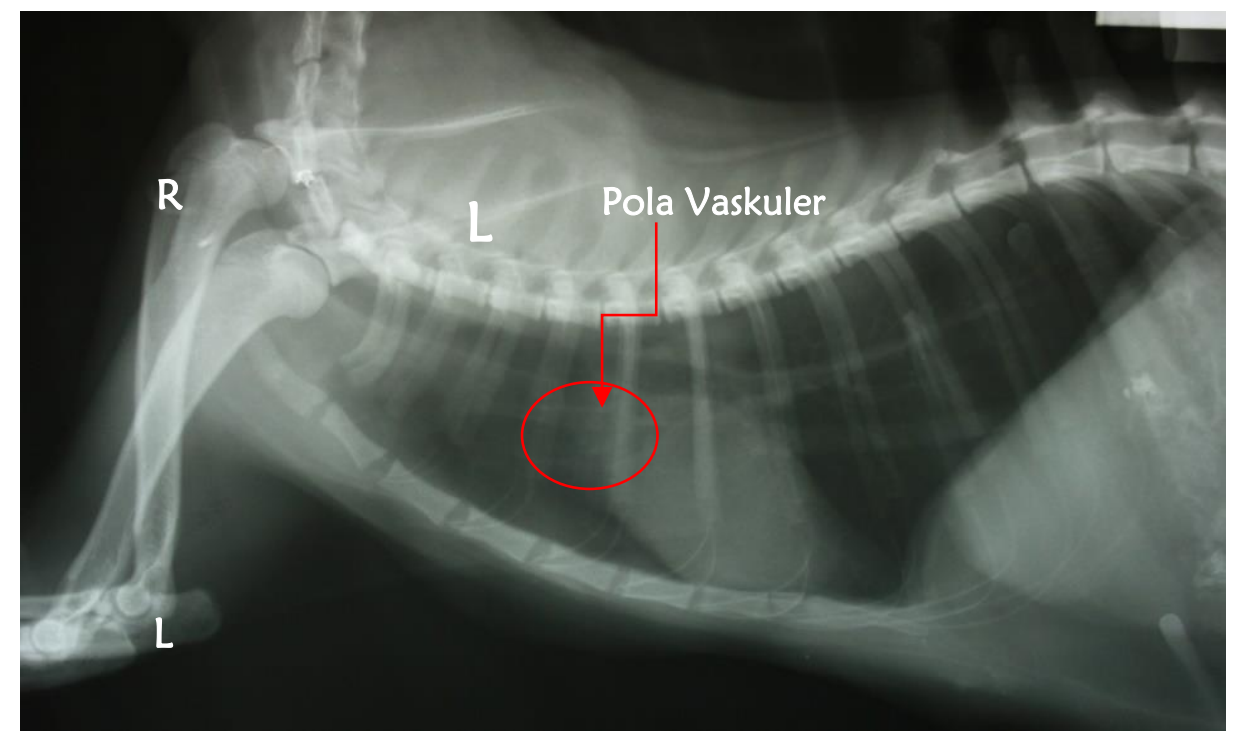

Figure 5. X-Ray Thorax Cat 3.

Sample 3, In the Lateral position we found the lungs that were more opaque (appear more white) than normal appearanced and the presenced of swelled or enlargement of the anterior vena cava and pulmonary veins. It was a vascular pattern. 


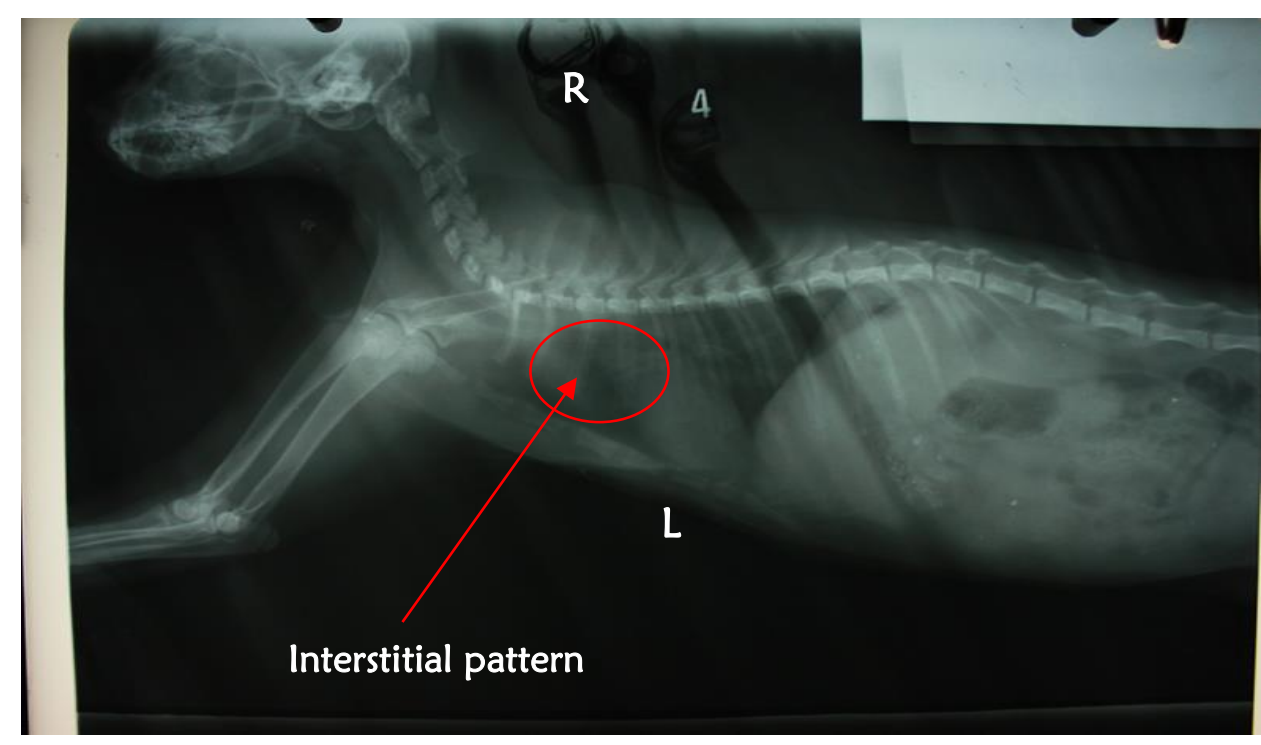

Figure 5. X-ray Thorax Cat 4

Cat sample 5. Ventro-dorsal position in the photo showed the interpretation of the lungs there was a change in the image of unstructured nodules around the lung area. We called the pattern of change as interstitial pattern.

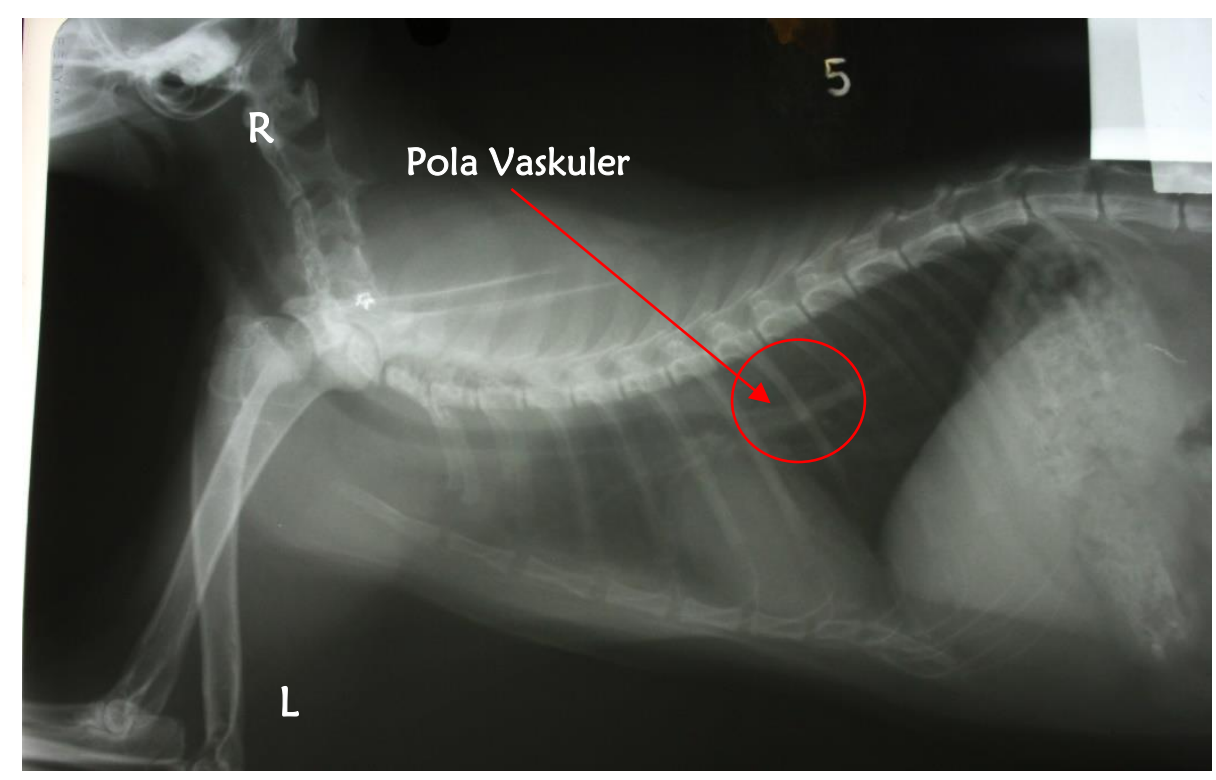

Figure 6. X-Ray Thorax Cat 5

Cat sample 5. In the Lateral position we found enlargement of the pulmonary veins (vein pulmonary). It was a vascular pattern. 


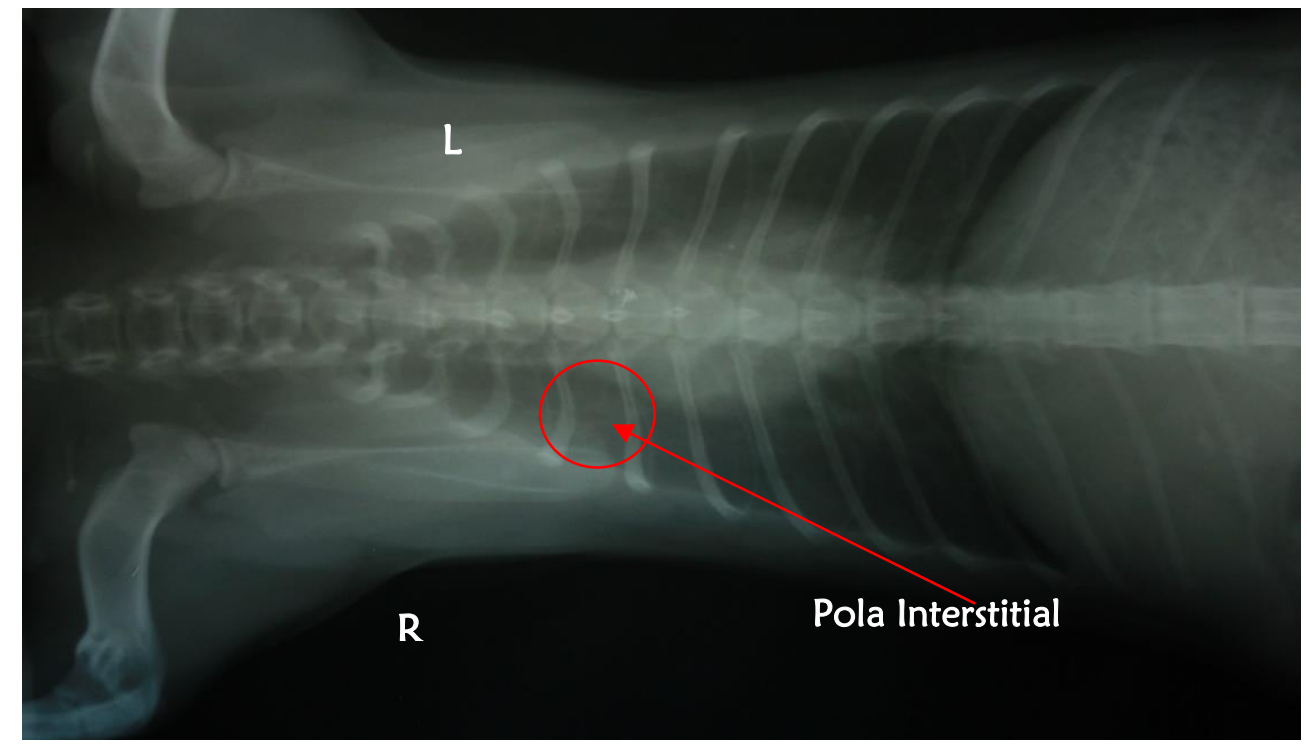

Figure 7. Thorax X-Ray Cat 6

Cat sample 6. Ventro-dorsal position in the photo showed the interpretation of the lungs there was a change in the image of unstructured nodules around the lung area. We called the pattern of change as interstitial pattern.

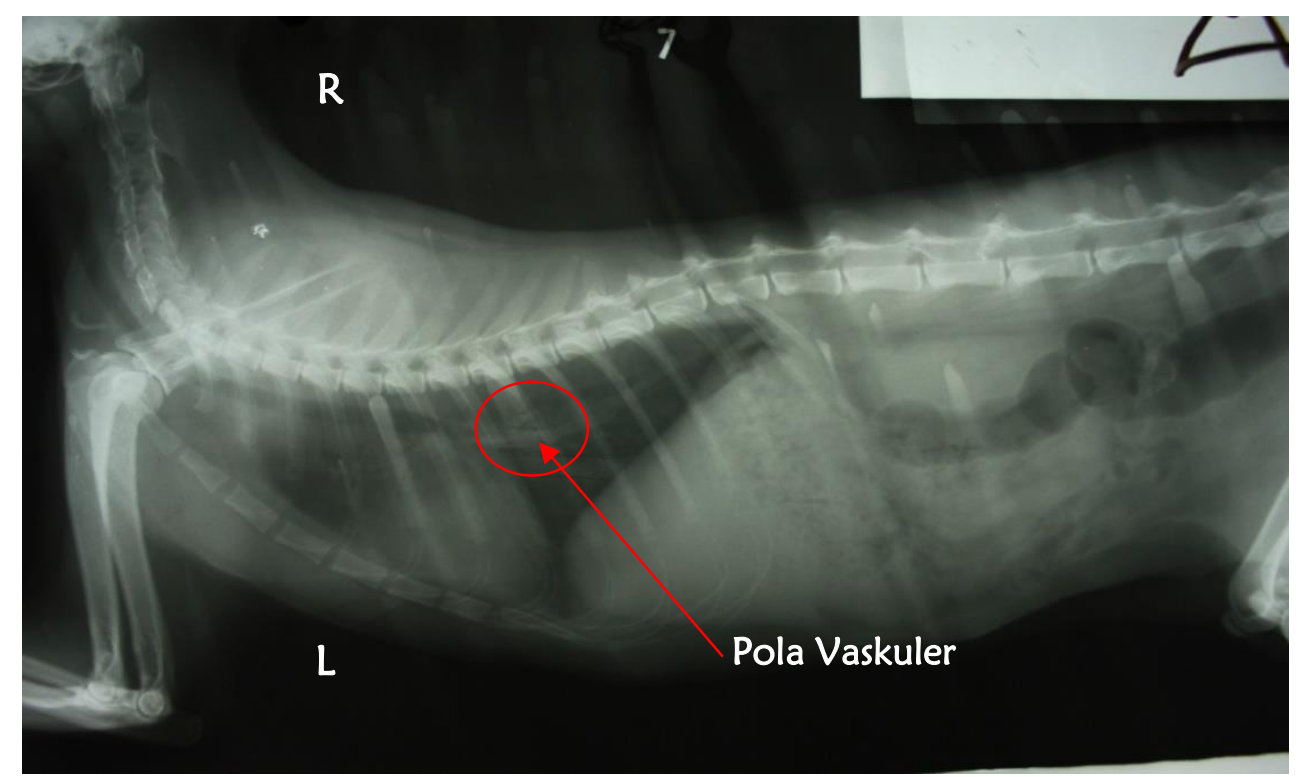

Figure 8. X-Ray Thorax Cat 7

Cat sample 7. Position of taking photographs with Lateral position found the interpretation of the lungs and enlargement of the pulmonary veins (vein pulmonary). Changes in patterns that occur are vascular. 


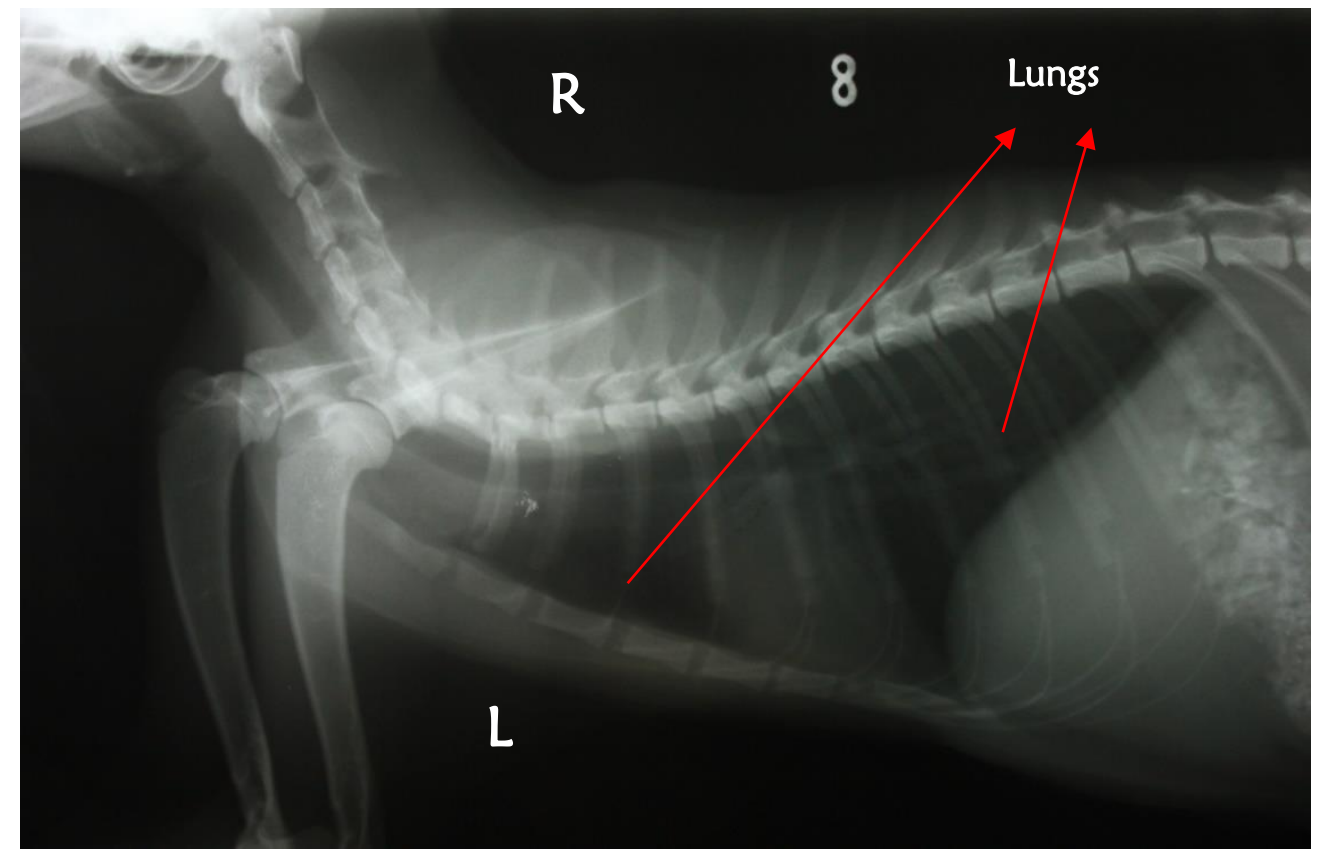

Figure 9. X-Ray Thorax Cat 8

Cat sample 8. Position of taking photographs with Lateral position found normal lung readings where no changes were found. The lungs look clean with radiolucent appearance.

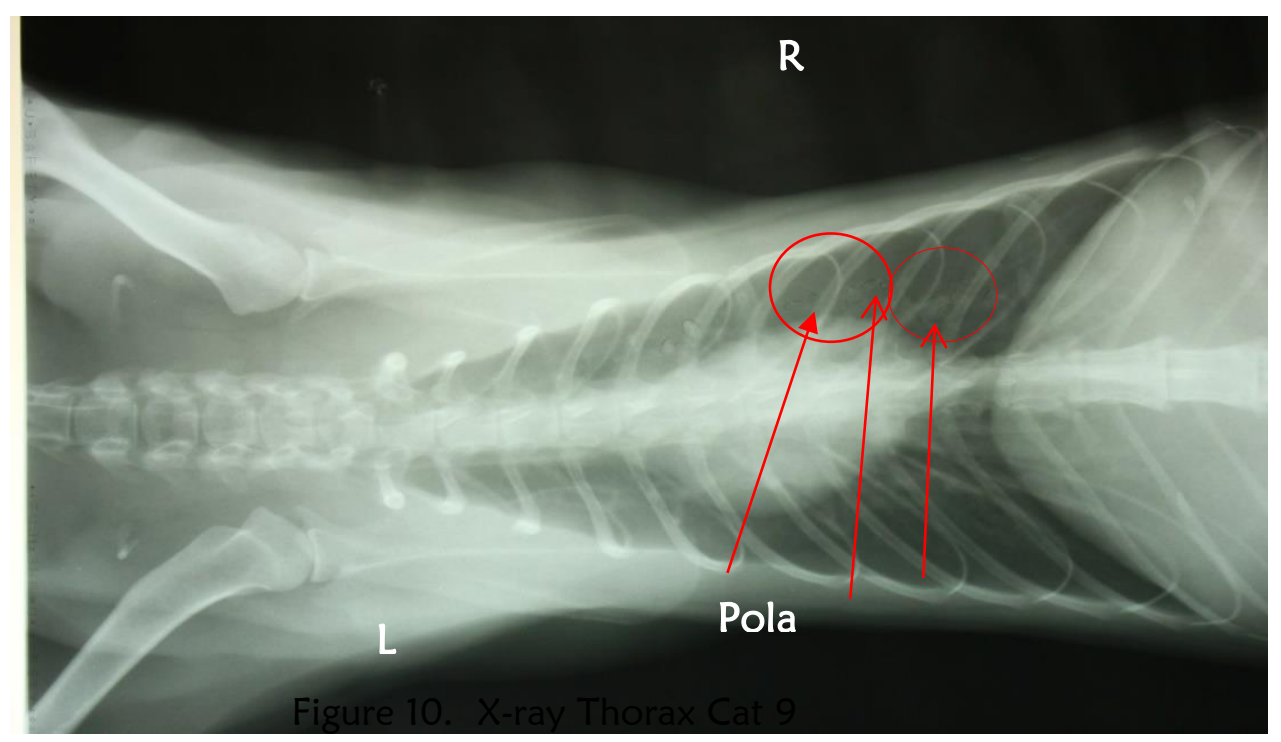

Figure 10. X-Ray Thorax Cat 9

Cat sample 9.Ventro-dorsal positions revealed the lungs interpretation that appear opaque images (appear whiter) in all lungs that spread thin like cotton (Interstitial change patterns) and images such as donat like (Bronchial pattern).

\section{Discussion}

The principle of interpretation a thoracic $X$-ray radiography is finding the indications in clinical situations such as respiratory diseases (pulmonary metastases), respiratory complications after surgery, heart disease or dyspnoea symptoms. While the contraindication was the amount of 
fluid in the pleura or the period in the thorax cause stress when shooting in the VD position, it was because the patient had difficulty breathing (dyspneu) due to pressure on the lungs.

Based on the radiographic description of the cat's thorax above the changes seen in the results of X-ray in this study are cats samples 3, 4, 5, 6, 7 and 9. In cats 3, 5 and 7 the same changes occurred, namely changes in Vascular patterns namely the enlargement, constriction or obscurity of the vascular structure of the lungs of the 3,5 and 7 cat samples. From these results the vaccine pattern indicated from left heart failure (Mitral Isufisiency) or left atrial obstruction (Noviana D, 2011). The relationship between air pollution to the possibility of heart failure with an indication of changes in blood vessels in the cat.

According to Fahri, I et al. (2009) states that the mechanism underlying systemic manifestations in chronic pulmonary disease becomes interesting, because many systemic manifestations were associated with morbidity and mortality rates for chronic lung disease patients. Appropriate assessment and management of systemic complications in chronic pulmonary disease is very important in developing advanced management and better outcomes in patients with chronic pulmonary disease. From several complications of systemic inflammation in patients with chronic pulmonary disease it was known that morbidity and mortality rates associated with cardiovascular complications were quite high. In subjects with chronic mild to moderate lung disease, there is a relationship between the systemic inflammation effects of chronic pulmonary disease on the cardiovascular system. The systemic inflammatory response was characterized by the mobilization and activation of inflammatory cells in circulation, acute phase protein production and an increase in inflammatory mediators. Oxidative stress from free radicals triggers endothelial dysfunction by reducing vasodilation, endothelial cell growth and increased plaque formation and tore in blood vessel walls.

According to Fahri, I et al. (2009) The effects of systemic inflammation on chronic lung disease can be understand from this description: Smoking or Exposure to Air Pollution can cause Chronic Lung Disease where Chronic Lung Disease is a Systemic Inflammation and Oxidative Stress which are the main factors causing Cardiovascular Disease, Weight Loss, Dysfunction Muscle Bones, Lung Cancer, Osteopenia and several other disorders of the Lungs.

In cat 9 there is a change in the appearance of the Bronchial pattern that is seen by calcification, dilation or thickening of the lungs. In cat 6 there is a noticeable change in the interstitial pattern of unstructured nodular features. And in cat 9 there is a picture like in both cats 4 and 6 where the changes that occur are visible interstitial and bronchial patterns. Interstitial patterns are structured nodular features and bronchial patterns are also seen as calcification, dilatation and thickening. Interstitial and bronchial patterns can occur in cases of interstitial pneumonia and also in bronchopneumonia (Sektiari.B, 2007). Pneumonia can occur from the result of infection or aspiration of fluid into the lungs, one of which is irritation, for example smoking and air pollution or it could be due to side effects from failure of other organs, especially the heart. Infection from the lungs can be caused by bacteria, viruses, and fungi (Foster, et al. 1997 in Hardiansyah, 2013).

Pneumonia is one of the inflammation (inflammation) acute or chronic in the lungs and bronchi with the characteristics of disorders in respiration and hypoxemia as well as complications from systemic effects. Generally caused by a primary infection by a virus in the lower respiratory tract. Canin distemper virus, type I and type II adenoviruses, influenza viruses, and feline caliciviruses that can cause distal respiratory tract lesions and the effect of bacterial infection in the lungs Parasitic invasion of bronchi by Filaroides, Aelurostrongly, and Paragonimus spp. cause pneumonia. Tuberculosis pneumonia is rarely found, but is often seen in dogs compared to cats. The incidence of mycotic granuloma pneumonia is also higher in dogs than in cats 
(Hardiansyah, 2013). According to Hardiansyah (2013), pneumonia is a general term that many people use to refer to pneumonia. This is different from bronchitis, which is inflammation of the bronchi. However, bronchitis and pneumonia quite often occur together, hence it is called bronchopneumonia. Whereas interstitial pneumonia is pneumonia that is commonly found in septa and peribronchial and peri-vascular connective tissue.

\section{References}

Ali, A.R., 2007. Kajian Pustaka Kebijakan Pencemaran Udara Di Indonesia. Polewali Mandar. http://arali2008.wordpress.com. [5 Maret 2015]

Anonim., 2007. Pemeriksaan Paru. Modul SkillabA-JILID I http://kedokteran. unsoed.ac.id/files/labskill/PemeriksaanParu.pdf. [8 Maret 2015]

Fahri, I., Dianiati K.S dan Yunus, F., 2009. Efek Peradangan Sistemik PadaPPOK Terhadap Sistem Kardiovaskular. Jakarta. Departemen IImu Penyakit Jantung dan Kedokteran Vaskular Fakultas Kedokteran Universitas Indonesia.

Galiono, J., 2014. Standart Posisi dan Interpretasi Radiografi. Surabaya. Bahan Ajar Fakultas Universitas Airlangga.

Hardiansyah., 2013. Pneumonia interstitial pada anjing dan Laporan di Banda Aceh. http://bgenk-veteriner.blogspot.com/2013/01/pneumonia-interstitial-pada-anjingdan.html. [diakses pada Juli 2015]

Indrawan, W., Gunawan, I dan Alhamdi, M.R., 2014. Rumah Sakit Hewan Di Kota Pontianak. Pontianak. Volume : 2 No. 1.

Kardiawarman., 1996. Sinar-X. Bandung. Diseminarkan di Jurusan Pendidikan Fisika Pada tgl 18 September 1996.

Mariandayani, H.N., 2012. Keragaman Kucing Domestik (felis domesticus) berdasarkan Morfogenetik. Jakarta. Volume : 1 No. 1.

Noviana, D., 2011. Principles of Thoracic Radiography (Heart and Lung). Thorac Radiografi Hand Out Materi ADHPHKI 16 Juli 2011. Staf Bagian Bedah dan Radiologi. Bogor. Fakultas Kedokteran Hewan Institut Pertanian Bogor.

Julien, S., 2007. Tata Letak. Surabaya. Buku Ajar Fakultas Kedokteran Hewan Universitas Airlangga.

Sektiari, B., 2007. Interpretasi Radiografi Thorax dan Abdomen. Surabaya. Buku Ajar Departemen Klinik Veteriner Fakultas Kedokteran Hewan Uiversitas Airlangga.

Simanjuntak, A.G., 2007. Pencemaran Udara. Buletin Limbah Volume : 11 no.1

Sugiarti., 2009. Gas Pencemar Udara Dan Pengaruhnya Bagi Kesehatan Manusia. Makassar. Jurnal Chemica Vol. 10 Nomor 1, 50-58

Sulaiman., 2010. Berbisnis Pembibitan Kucing-Dari Hobi Jadi Uang. Yogyakarta. Lily Publisher.

Suradi., 2007. Pengaruh Rokok Pada Penyakit Paru Obstruksi Kronik (PPOK) Tinjauan Patogenesis, Klinis Dan Sosial. Surakarta. Diseminarkan pada Sidang Senat Terbuka Universitas Sebelas Maret Surakarta Pada tanggal 10 Maret 2007.

Suyatno, F., 2008. Aplikasi Radiasi Sinar-X Di Bidang Kedokteran Untuk Menunjang Kesehatan Masyarakat. Banten : Pusat Rekayasa Perangkat Nuklir BATAN.

Widyananta, Budhy Jasa, Chaindra Prasto Saleh, Deni Noviana, Dwi Utari Rahmiati, Gunanti, Mokhamad Fakhrul Ulum, R. Harry Soehartono, Rr. Soesatyoratih, Riki Siswandi, Siti Zaenab. 2017. Atlas of Normal Radiography in Dogs and Cats.IPB Press, IPB Science Techno Park, Kota Bogor, Indonesia.

Wulan, T.D., Purwanti, E dan Yasin, M., 2013. Deteksi Kanker Paru-Paru Dari Citra Foto Rontgen Menggunakan Jaringan Syaraf Tiruan Backpropagation. Surabaya. Volume : 1 no. 1.

Yudi., 2009. Penyakit Pada Kucing. http://drhyudi.blogspot.com/2009/02/penyakit-padakucing.html. [8 Maret 2015] 